\title{
Rapid, Refined, and Robust Method for Expression, Purification, and Characterization of Recombinant Human Amyloid beta 1-42
}

\author{
Priya Prakash ${ }^{1,+}$, Travis C. Lantz $^{1, \dagger}$, Krupal P. Jethava $^{1}$ and Gaurav Chopra $1,2,3,4,5, * \mathbb{C}$ \\ 1 Department of Chemistry, Purdue University, West Lafayette, IN 47907, USA; prakashp@purdue.edu (P.P.); \\ tclantz@purdue.edu (T.C.L.); kjethava@purdue.edu (K.P.J.) \\ 2 Purdue Institute for Drug Discovery, Purdue University, West Lafayette, IN 47907, USA \\ 3 Purdue Institute for Integrative Neuroscience, Purdue University, West Lafayette, IN 47907, USA \\ 4 Purdue Institute for Inflammation, Immunology and Infectious Disease, Purdue University, West Lafayette, \\ IN 47907, USA \\ 5 Purdue Center for Cancer Research, Purdue University, West Lafayette, IN 47907, USA \\ * Correspondence: gchopra@purdue.edu; Tel.: +1-765-496-6108 \\ + These authors contributed equally to the paper.
}

Received: 16 April 2019; Accepted: 3 June 2019; Published: 7 June 2019

\begin{abstract}
Amyloid plaques found in the brains of Alzheimer's disease patients primarily consists of amyloid beta 1-42 (A $\beta 42$ ). Commercially, $A \beta 42$ is synthesized using high-throughput peptide synthesizers resulting in the presence of impurities and the racemization of amino acids that affects its aggregation properties. Furthermore, the repeated purchase of even a small quantity $(\sim 1 \mathrm{mg})$ of commercial $\mathrm{A} \beta 42$ can be expensive for academic researchers. Here, we describe a detailed methodology for robust expression of recombinant human A $\beta(\mathrm{M} 1-42)$ in Rosetta(DE3)pLysS and BL21(DE3)pLysS competent $E$. coli using standard molecular biology techniques with refined and rapid one-step analytical purification techniques. The peptide is isolated and purified from transformed cells using an optimized reverse-phase high-performance liquid chromatography (HPLC) protocol with commonly available C18 columns, yielding high amounts of peptide ( 15-20 mg per $1 \mathrm{~L}$ culture) within a short period of time. The recombinant human $A \beta(M 1-42)$ forms characteristic aggregates similar to synthetic $A \beta 42$ aggregates as verified by western blotting and atomic force microscopy to warrant future biological use. Our rapid, refined, and robust technique produces pure recombinant human $\mathrm{A} \beta(\mathrm{M} 1-42)$ that may be used to synthesize chemical probes and in several downstream in vitro and in vivo assays to facilitate Alzheimer's disease research.
\end{abstract}

Keywords: amyloid beta; recombinant abeta; HPLC; expression; purification; neuroscience; peptide; neurodegeneration; Alzheimer's disease

\section{Introduction}

Amyloid beta 1-42 (A $\beta 42)$ is a small $\sim 4 \mathrm{kDa}$ peptide produced when the amyloid precursor protein expressed on neuronal membranes is sequentially cleaved by $\beta$-secretase and $\gamma$-secretase [1]. A $\beta$ exists as several variants ranging from 36 to 43 amino acid residues [2]. However, the main component of the toxic amyloid plaques found in the brains of Alzheimer's Disease (AD) patients is composed of the $A \beta 42$ isoform [3]. The extracellular accumulation of $A \beta 42$ in the brain over time contributes to neuronal dysfunction and death leading to progressive memory loss and cognitive decline [4].

Several therapeutics currently in preclinical and clinical trials for AD are focused on targeting the cellular and molecular mechanisms related to $A \beta 42[5,6]$. Thus, there is an immediate need for further understanding of $A \beta 42$ 's biological function and its effect on both neurons and non-neuronal glial 
cells [7-9]. Researchers commonly use commercially-available synthetic A $\beta 42$ for their experiments. However, the repeated purchase of synthetic $\mathrm{A} \beta 42$ can be expensive ( $\$ 300$ for $1 \mathrm{mg}$ of peptide). Synthesizing $A \beta 42$ in a traditional biochemistry laboratory has additional hurdles, such as 1) being expensive due to high instrument costs and 2) challenging due to the high hydrophobicity of the peptide that can affect the yield and efficiency of the procedure. The C-terminal sequence of $A \beta 42$ in particular is known to be resistant to solid-phase peptide synthesis and is therefore called a "difficult sequence" peptide [10]. Furthermore, the presence of impurities and the racemization of amino acids during the synthesis of $A \beta$ affects its aggregation properties. It has been shown that synthetic $A \beta$ has lower aggregation kinetics and decreased neurotoxicity compared to recombinant human $A \beta$ [11]. Thus, recombinant human $A \beta$ is not only cheaper and easier to produce than the synthetic peptide but it is also free of enantiomers and is therefore better for investigating the biochemical and biological activity of $A \beta$.

Here, we present an alternate and refined approach for the rapid, easy, and low-cost production and purification of recombinant human $\mathrm{A} \beta 42$ containing an exogenous $\mathrm{N}$-terminus methionine, denoted as $\mathrm{A} \beta(\mathrm{M} 1-42)$. The pET-Sac-Abeta(M1-42) plasmid was developed previously by Walsh et al. and expresses $A \beta($ M1-42) in E. coli cells [12]. In this original protocol, a combination of anion-exchange chromatography and centrifugal filtration was used to purify the peptide. Further, it was demonstrated that the exogenous methionine does not affect the kinetics and the fibrillation process of $A \beta(M 1-42)$ compared to $A \beta 42$ [12]. Thus, the recombinant human $A \beta(M 1-42)$ and synthetic $A \beta 42$ both exhibit aggregate-forming properties. The concentration-dependent aggregation kinetics of the $A \beta(M 1-42)$ and its variants with different $\mathrm{N}$-terminal sequence extensions have also been previously evaluated [13]. In this protocol, we will focus on the expression of the recombinant $A \beta(\mathrm{M} 1-42)$ peptide, its one-step purification using HPLC, and the morphology characterization of the purified peptide.

Recently, Yoo et al. published a protocol where the $A \beta(\mathrm{M} 1-42)$ peptide was purified using reverse-phase high-performance liquid chromatography (HPLC) [14]. We have further expanded and optimized this protocol with the following changes to provide improved versatility to the method: 1) We have expressed the pET-Sac-Abeta(M1-42) plasmid in Rosetta(DE3)pLysS cells (a BL21 derivative designed to enhance the expression of eukaryotic proteins) in addition to the BL21(DE3)pLysS cells; 2) We have performed the purification of the peptide with HPLC using the commonly available C18 columns with optimized solvent system conditions; 3) We have provided characteristic details of the peptide with Matrix-Assisted Laser Desorption/Ionization Time-Of-Flight Mass Spectrometry (MALDI-TOF MS) and verified its characteristic aggregate formations in different conditions by western blotting and Atomic Force Microscopy (AFM) to warrant future biological use.

\section{Experimental Design}

The protocol detailed in this paper can be divided into five parts (Figure 1). The pET-Sac-Abeta(M1-42) plasmid is isolated (Part 1), transformed in the competent $E$. coli (Part 2), and the expression of A $\beta($ M1-42) peptide is induced in a large quantity of bacterial culture (Part 3). Expressing human $A \beta(M 1-42)$ in E. coli is a highly efficient and feasible method to produce large quantities of the peptide. Our protocol can be completed within a week's time ( five days if starting from the beginning or three days if using the transformed bacteria for generating more cultures for peptide purification) and a yield of around $15-20 \mathrm{mg}$ of the peptide per $1 \mathrm{~L}$ of the culture can be obtained. The equipment utilized for the expression and purification of the peptide are readily available in not only biological labs, but also in synthetic chemistry and chemical biology labs, therefore promoting widespread use of the method.

The expressed peptides are present as inclusion bodies within the bacterial cells that are then isolated by repeated sonification and lysed with Tris/EDTA buffers followed by dissolution of the peptide into $8 \mathrm{M}$ urea buffer (Part 4). The peptide is ultimately purified by reverse-phase HPLC using the C18 columns with an optimized solvent system for peptide purification (Part 5). C18 columns are popular and conventionally used for the separation of small molecules and low molecular weight peptides. Typically a relatively large (43 residues) and hydrophobic peptide like A $\beta(M 1-42)$ [3] is not 
separated with a C18 column. However, heating the column between $60-80{ }^{\circ} \mathrm{C}$ results in a single peak during separation of pure $A \beta(M 1-42)$ peptide with yields similar to alternative protocols [12-14]. The lyophilized peptide is characterized by mass spectrometry to verify the identity of the peptide and to detect any impurities present. The aggregation characteristics of the recombinant $\mathrm{A} \beta(\mathrm{M} 1-42)$ are similar to the synthetic $A \beta 42$ peptide as per AFM and western blotting with monoclonal antibody.

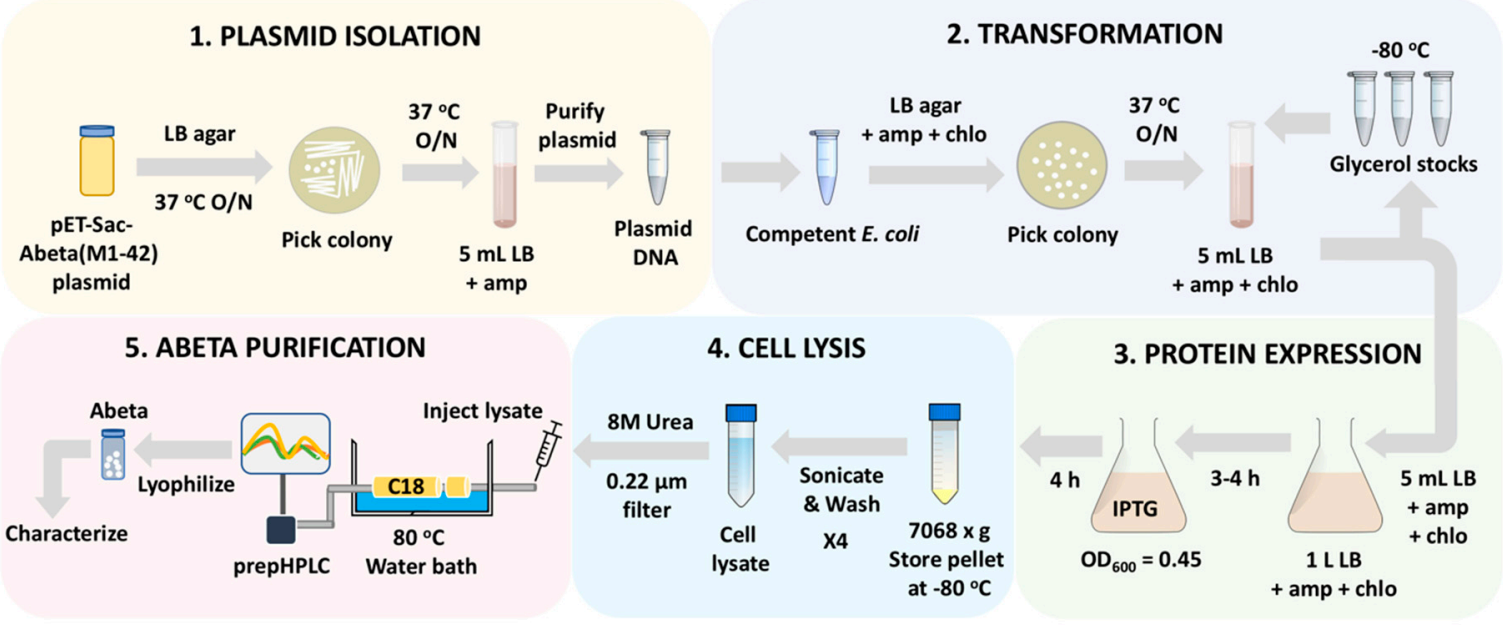

Figure 1. Schematic diagram illustrating the experimental protocol for the expression and isolation of recombinant human $\mathrm{A} \beta(\mathrm{M} 1-42)$ peptide from competent E. coli. The protocol can be divided into five main parts: Part 1. Isolation of the pET-Sac-A $\beta(\mathrm{M} 1-42)$ plasmid from the glycerol stock; Part 2. Transformation of BL21(DE3)pLysS and Rosetta(DE3)pLysS competent cells with the isolated pET-Sac-A $\beta($ M1-42) plasmid; Part 3. Expression of the A $\beta(M 1-42)$ peptide in 1 L liquid LB culture; Part 4. Harvesting and lysis of the cells using a probe sonicator followed by resuspension of the cell lysate in $8 \mathrm{M}$ urea; and Part 5. Purification of the A $\beta(\mathrm{M} 1-42)$ peptide with preparative HPLC.

\subsection{Materials}

- $\quad$ pET-Sac-Abeta(M1-42) plasmid (Addgene, Watertown, MA, USA; Cat. no.: 71875)

- $\quad$ Tryptone (Fisher Scientific, Waltham, MA, USA; Cat. no.: BP1421-500)

- Yeast Extract (Fisher Scientific, Waltham, MA, USA; Cat. no.: BP9727-500)

- LB Agar (Miller, Granulated) (Fisher Scientific, Waltham, MA, USA; Cat. no.: BP9724-500)

- Ampicillin (VWR International, Radnor, PA, USA, Cat. no.: 80055-786)

- Chloramphenicol (Fisher Scientific, Waltham, MA, USA; Cat. no.: AAJ67273AB)

- $\quad$ Plasmid Miniprep System (Promega, Madison, WI, USA; Cat. no.: A12222)

- $\quad$ Rosetta $^{\mathrm{TM}}(\mathrm{DE} 3)$ LysS Competent Cells (MilliporeSigma, Burlington, MA, USA; Cat. no.: 70956-3)

- Isopropyl $\beta$-D-1- thiogalactopyranoside (IPTG) (Fisher Scientific, Waltham, MA, USA; Cat. no.: 15-529-019)

- $\quad$ Tris hydrochloride (Tris-HCl) (Fisher Scientific, Waltham, MA, USA; Cat. no.: BP153-500)

- Urea (Invitrogen, Carlsbad, CA, USA; Cat. no.: 15505-035)

- $0.22 \mu \mathrm{m}$ non-sterile hydrophilic PVDF syringe filter (Fisher Scientific, Waltham, MA, USA; Cat. no.: 09-719-000)

- $\quad$ HPLC grade Acetonitrile (Fisher Scientific, Waltham, MA, USA; Cat. no.: A998-4)

- $\quad$ Purified anti- $\beta$-Amyloid, 1-16 Antibody (BioLegend, San Diego, CA, USA; Cat. no.: 803001)

- HRP Goat anti-mouse IgG (minimal x-reactivity) Antibody (BioLegend, San Diego, CA, USA; Cat. no.: 405306)

- SuperSignal West Pico Chemiluminescent Substrate (Fisher Scientific, Waltham, MA, USA; Cat. no.: 34080) 
- 1,1,1,3,3,3-Hexafluoroisopropyl alcohol (Chem-Impex International, Wood Dale, IL, USA; Cat. no.: 00080)

- Hamilton syringe with a Teflon plunger and a sharp needle [Hamilton Company, Reno, NV, USA; Part. no.: 81343]

- Mica sheet (Ted Pella, Redding, CA, USA; Cat. no.: 50)

- Aluminum coated silicon probes with resonant frequency $\sim 300 \mathrm{kHz}$ and $40 \mathrm{~N} / \mathrm{m}$ force constant (Ted Pella, Redding, CA, USA; Cat. no.: TAP300AL-G-10)

- Phosphate-buffered saline (PBS), 10x at pH 7.4 (Alfa Aesar, Haverhill, MA, USA; Cat. no.: J62036-K7)

\subsection{Equipment}

- Benchtop incubator shaker (New Brunswick ${ }^{\mathrm{TM}}$ Excella®E24) (Eppendorf, Hamburg, Germany; Cat. no.: M1352-0000)

- Sonicator Ultrasonic Homogenizer (125W) with 1/4" Probe (Qsonica, Newton, CT, USA; Cat. no.: Q700-110 and 4435)

- $\mathrm{CO}_{2}$ Incubator (New Brunswick ${ }^{\mathrm{TM}}$ Galaxy $(48 \mathrm{~S})$ (Eppendorf, Hamburg, Germany; Cat. no.: CO48S-120-0000)

- Centrifuge (Sorvall LYNX 6000) with a Swinging-Bucket Rotor (BIOFlex ${ }^{\mathrm{TM}} \mathrm{HC}$ ) (Thermo Fisher Scientific, Waltham, MA USA; Cat. no.: 75006591 and 75003000)

- UV-Visible Spectrophotometer (JASCO, Easton, MD, USA; Cat. no.: V-730)

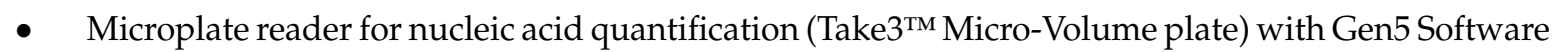
(BioTek, Winooski, VT, USA; Cat. no.: TAKE3)

- Combiflash EZ prep UV/ELSD (Teledyne ISCO, Lincoln, NE, USA; Cat. no.: 218J00936)

- $\quad$ RediSep Prep $10 \times 250$ mm C18 100A, $5 \mu \mathrm{m}$ column (Teledyne ISCO, Lincoln, NE, USA; Cat. no.: 692203809)

- $\quad$ RediSep Prep Guard $20 \times 30$ mm, C18Aq, 100A, $5 \mu \mathrm{m}$ (Teledyne ISCO, Lincoln, NE, USA; Cat. no.: 692203805)

- GenPure UV/UF $\times$ CAD plus Ultrapure Water Purification System (Thermo Fisher Scientific, Waltham, MA USA; Cat. no.: 41956240)

- Rotary evaporator and water bath (EYELA, Keyland Court Bohemia, NY, USA; Cat. no.: N-1110 and SB-1200)

- $\quad$ Dry Bath with heating block (Thermo Fisher Scientific, Waltham, MA USA; Cat. no.: 88870002)

- Labconco Freezone 12 Liter Console Freeze Dry System (Lyophilizer) (Labconco, Kansas City, MO, USA; Cat. no.: 710612000)

- Voyager-DE PRO (MALDI-TOF mass spectrometer) (Applied Biosystems, Foster City, CA, USA;)

- For AFM: Veeco Multimode instrument with NanoScope V controller

\section{Procedure}

\subsection{Preparation of Solutions}

Use ultrapure water to prepare all the solutions in the protocol. Make liquid Luria Broth (LB) by dissolving $10 \mathrm{~g}$ tryptone, $10 \mathrm{~g} \mathrm{NaCl}$, and $5 \mathrm{~g}$ yeast extract in $1 \mathrm{~L}$ water. Autoclave the liquid $\mathrm{LB}$ and bring to room temperature before adding the antibiotics. Prepare solid LB as $3.2 \mathrm{~g}$ of LB agar mix in $100 \mathrm{~mL}$ water. Autoclave the broth and allowed to cool before adding the antibiotics as follows: (i) $100 \mathrm{mg} / \mathrm{L}$ ampicillin for antibiotic selection during amplification of the $\mathrm{pET}-\mathrm{Sac}-\mathrm{A} \beta(\mathrm{M} 1-42)$ plasmid in LB media and (ii) $100 \mathrm{mg} / \mathrm{L}$ ampicillin and $34 \mathrm{mg} / \mathrm{L}$ chloramphenicol for maintenance and expression of the A $\beta$ (M1-42) peptide in Rosetta(DE3)pLysS and BL21(DE3)pLysS strains (i.e., for transformed bacteria). For solid LB preparation, pour the media with the antibiotics on to the Petri dishes and keep in the biosafety cabinet with lids open to allow the media to solidify. Prepare these plates in bulk and 
refrigerate at $4{ }^{\circ} \mathrm{C}$ for future use to save time during the protocol. For cell lysis steps, make two buffers: (i) Buffer A containing $10 \mathrm{mM}$ Tris/ $\mathrm{HCl}$ and $1 \mathrm{mM}$ EDTA in water (pH 8.0), (ii) Buffer B containing $8 \mathrm{M}$ urea, $10 \mathrm{mM}$ Tris $/ \mathrm{HCl}$, and $1 \mathrm{mM}$ EDTA in water ( $\mathrm{pH}$ 8.0). Prepare fresh buffers each time. For peptide purification with preparative HPLC, make: (i) Solvent A as $0.1 \%$ trifluoroacetic acid (TFA) in water and (ii) Solvent B as $0.1 \%$ TFA in acetonitrile (Table 1). TFA is a common ion-pairing agent used in reverse phase-HPLC to enhance the separation of large hydrophobic peptides and is volatile and easily removed from the purified peptide. Acetonitrile is a common organic solvent used to elute peptides as it has low viscosity and is easy to evaporate off.

Table 1. Solvent gradient for the cleaning protocol done before and after peptide purification.

\begin{tabular}{|c|c|c|}
\hline$\%$ Solvent $\mathrm{A}^{1}$ & $\%$ Solvent B ${ }^{2}$ & Elapsed Time (min) \\
\hline 90 & 10 & 0 \\
\hline 90 & 10 & 5 \\
\hline 10 & 90 & 10 \\
\hline 10 & 90 & 20 \\
\hline
\end{tabular}

\subsection{Expression of $A \beta(M 1-42)$ Peptide. Time for Completion: $55: 30 \mathrm{~h}$}

3.2.1. Isolation of the pET-Sac-A $\beta(M 1-42)$ Plasmid. Time for Completion: 31:00 h

Note: The bacterial growth on solid agar as well as in liquid culture are performed at $37^{\circ} \mathrm{C}$ temperature which is the optimal growth temperature for E. coli cells.

1. Streak the bacteria onto a solid LB agar plate containing $100 \mathrm{mg} / \mathrm{L}$ ampicillin using a sterile loop. Note: The $\mathrm{pET}-\mathrm{Sac}-\mathrm{A} \beta(\mathrm{M} 1-42)$ plasmid arrives as a bacterial agar stab culture.

2. Keep the plate overnight for $\sim 16 \mathrm{~h}$ in the incubator at $37^{\circ} \mathrm{C}$ for the colonies to grow.

3. The next day, pick a single colony from the plate (Figure $2 \mathrm{~A}$ ) using a sterile loop or a sterile $10 \mu \mathrm{L}$ pipet tip and inoculate into $5 \mathrm{~mL}$ of liquid LB containing $100 \mathrm{mg} / \mathrm{L}$ ampicillin.

4. Keep the culture in a shaking incubator at $220 \mathrm{rpm}$ and $37^{\circ} \mathrm{C}$ overnight for $\sim 16 \mathrm{~h}$.

5. The next day, isolate the plasmid (Figure 1, Part 1) from the culture using the plasmid isolation miniprep kit following instructions per the user manual.

6. Measure the concentration of the plasmid at $260 \mathrm{~nm}$ absorbance using a spectrophotometer for nucleic acid quantification. Note: Typical plasmid yield is around $45-55 \mathrm{ng} / \mu \mathrm{L}$ from $5 \mathrm{~mL}$ liquid LB culture.

3.2.2. Transformation of pET-Sac-A $\beta(M 1-42)$ Plasmid into Competent E. Coli by Heat Shock Method. Time for Completion: 01:30 h

1. To transform the $\mathrm{A} \beta(\mathrm{M} 1-42)$ plasmid into E. coli (Figure 1, Part 2), thaw the frozen vials of Rosetta(DE3)pLysS cells or BL21(DE3)pLysS competent cells (20-50 $\mu \mathrm{L})$ on ice.

2. Once thawed, add around $1-2 \mu \mathrm{L}$ of the isolated plasmid (to have 50-100 ng total DNA) to the cells and gently flick the tube a few times to mix the plasmid with the cells.

3. Incubate the cells and the plasmid mixture on ice for $20 \mathrm{~min}$ and then place the tube in a $42{ }^{\circ} \mathrm{C}$ water bath for $45 \mathrm{~s}$ to facilitate the transformation of plasmid into the cells via heat shock method.

4. After heat shock, immediately place the tubes on ice for 2 mins. Inoculate the transformed bacteria into $500 \mu \mathrm{L}$ of liquid LB media without any antibiotics and keep the tube in the $37^{\circ} \mathrm{C}$ shaker for $1 \mathrm{~h}$ at $220 \mathrm{rpm}$.

A CRITICAL STEP: The transformed bacteria is first inoculated in liquid LB media without any antibiotics for $1 \mathrm{~h}$ to allow the bacteria to express the antibiotic resistance proteins necessary for future steps. 


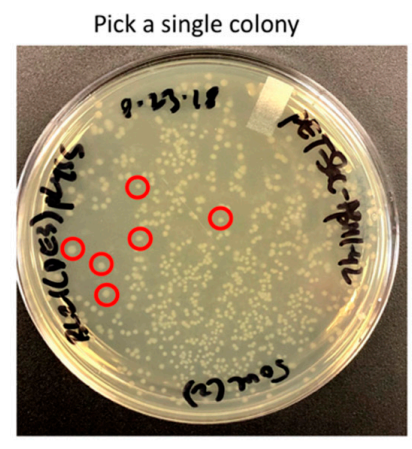

A
Inoculate in $5 \mathrm{~mL} \mathrm{LB}(\mathrm{O} / \mathrm{N})$

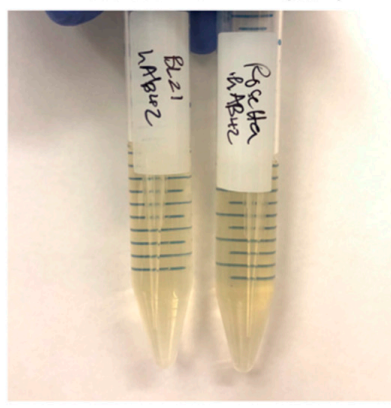

B

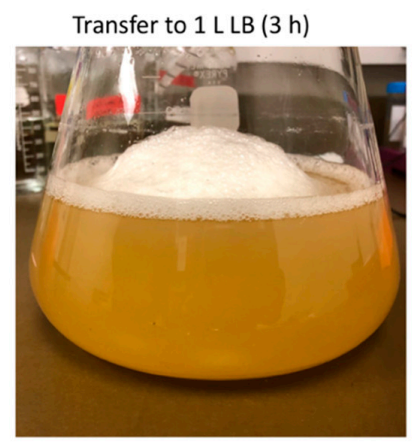

C

Figure 2. Transformed cells as colonies on the Luria Broth (LB) plate and the growing culture in liquid LB. A. Colonies of transformed E. coli on solid LB. Red circles represent single colonies. B. Single colony is picked from the plate and inoculated into $5 \mathrm{~mL}$ liquid $\mathrm{LB}$ and shaken at $37^{\circ} \mathrm{C}$ overnight that makes a cloudy solution after incubation. C. The next morning, this culture is inoculated into $1 \mathrm{~L}$ LB to grow the cells for the next 3 to $3.5 \mathrm{~h}$ until the optical density (OD) reaches 0.45 .

3.2.3. Expression of $A \beta(M 1-42)$ Peptide by the Transformed E. Coli. Time for Completion: 23:00 $\mathrm{h}$

1. After $1 \mathrm{~h}$, spread around $25-30 \mu \mathrm{L}$ (out of $500 \mu \mathrm{L}$ ) of the transformed cells onto solid LB agar plates containing $100 \mathrm{mg} / \mathrm{L}$ ampicillin and $34 \mathrm{mg} / \mathrm{L}$ chloramphenicol using a sterile glass spreader.

2. Let the plates sit in the biosafety cabinet for $5 \mathrm{~min}$ to allow the cells to absorb on the solid LB.

3. Next, keep the plates overnight in the incubator at $37^{\circ} \mathrm{C}$ for the transformed colonies to grow.

4 CRITICAL STEP: It is best to use a lower volume of the transformed cells $(25-30 \mu \mathrm{L})$ as this results in more single colonies that are easier to pick and prevents overcrowding on the plate.

4. The next day, pick a single colony from the plate using a sterile loop or a sterile $10 \mu \mathrm{L}$ pipet tip and inoculate into $5 \mathrm{~mL}$ of liquid LB containing $100 \mathrm{mg} / \mathrm{L}$ ampicillin and $34 \mathrm{mg} / \mathrm{L}$ chloramphenicol (first culture).

5. OPTIONAL STEP: At the same time, pick another single colony of the transformed bacteria and inoculate into a second $5 \mathrm{~mL}$ liquid LB media containing $100 \mathrm{mg} / \mathrm{L}$ ampicillin and $34 \mathrm{mg} / \mathrm{L}$ chloramphenicol for overnight growth (second culture). This culture will be used to make frozen glycerol stocks for future use.

6. Place both the cultures in the shaking incubator at $220 \mathrm{rpm}$ at $37^{\circ} \mathrm{C}$ overnight $(16 \mathrm{~h})$ (Figure 2B).

7. The following day, inoculate the first $5 \mathrm{~mL}$ culture into a large $2 \mathrm{~L}$ Erlenmeyer flask containing $1 \mathrm{~L}$ liquid LB media with $100 \mathrm{mg} / \mathrm{L}$ ampicillin and $34 \mathrm{mg} / \mathrm{L}$ chloramphenicol (Figure 2C).

8. Keep this $1 \mathrm{~L}$ culture at $220 \mathrm{rpm}$ and $37^{\circ} \mathrm{C}$ until the cell density reaches an optical density (OD) value between 0.40 to 0.45 at $600 \mathrm{~nm}\left(\mathrm{OD}_{600}\right)$.

4 CRITICAL STEP: The BL21(DE3)pLysS cells reach an $\mathrm{OD}_{600}$ between 0.40 to 0.45 in $3 \mathrm{~h}$ time, whereas the Rosetta(DE3)pLysS cells requires around 3.5-4.0 $\mathrm{h}$ to reach an $\mathrm{OD}_{600}$ between 0.40 to 0.45 . It is best to measure the OD of the culture at regular $20 \mathrm{~min}$ intervals starting from the 3-h time point before proceeding to the next step.

9. OPTIONAL STEP: The second $5 \mathrm{~mL}$ culture of transformed bacteria is used to make $25 \%$ glycerol stocks by adding $500 \mu \mathrm{L}$ of $50 \%$ glycerol to $500 \mu \mathrm{L}$ bacterial culture and is frozen at $-80{ }^{\circ} \mathrm{C}$ for future use. A $-80^{\circ} \mathrm{C}$ frozen glycerol stock of the transformed bacteria is thawed for use in the future for inoculating $5 \mathrm{~mL}$ liquid LB containing $100 \mathrm{mg} / \mathrm{L}$ ampicillin and $34 \mathrm{mg} / \mathrm{L}$ chloramphenicol to grow additional cultures of the transformed bacteria containing the $A \beta(M 1-42)$ plasmid. Note: Frozen aliquots of $250-500 \mu \mathrm{L}$ glycerol stocks may be stored for future use. It is recommended that the stored aliquots of glycerol stock be thawed 1-2 times only. Additionally, some of the frozen stock may be scrapped and thawed for inoculation.

1 CRITICAL STEP: This step serves as a starting point for all future experiments performed for the isolation of the $\mathrm{A} \beta(\mathrm{M} 1-42)$ peptide (Figure 1, Part 3). It is important to note that this step is 
critical for reducing the time taken for the entire protocol along with saving the reagents used for peptide expression.

10. Once the $\mathrm{OD}_{600}$ of the $1 \mathrm{~L}$ culture reaches 0.40 to 0.45 , induce protein expression by adding isopropyl $\beta$-D-1- thiogalactopyranoside (IPTG) to obtain a final concentration of $0.1 \mathrm{mM}$ in $1 \mathrm{~L}$ of the liquid LB media. Note: Add $1 \mathrm{~mL}$ of $0.1 \mathrm{M}$ IPTG stock solution prepared in water to obtain a final concentration of $0.1 \mathrm{mM}$ in $1 \mathrm{~L}$ LB media. Note: IPTG induction must occur early in the exponential growth phase to form insoluble inclusion bodies, which are essential for the isolation procedure.

11. Keep the culture again on the shaking incubator at $220 \mathrm{rpm}$ and $37^{\circ} \mathrm{C}$ for additional an $4 \mathrm{~h}$ in the presence of IPTG to allow the cells to express the A $\beta(\mathrm{M} 1-42)$ peptide.

12. After $4 \mathrm{~h}$, centrifuge the $1 \mathrm{~L}$ culture at $7068 \times \mathrm{g}$ at $4{ }^{\circ} \mathrm{C}$ for $25 \mathrm{~min}$. Note: The cultures are centrifuged at $4{ }^{\circ} \mathrm{C}$ temperature to arrest cell growth and metabolism. Note: Our centrifuge allowed for a maximum speed of $7068 \times \mathrm{g}$ with the corresponding swinging bucket rotor (see Section 2.2. Equipment). Hence, this speed was used to collect the transformed cells from the $1 \mathrm{~L}$ cultures. The cells may also be pelleted by centrifuging the cultures at 2800× $\mathrm{g}$ if using a JA-10 rotor [14].

13. Discard the supernatant liquid LB and resuspend the pelleted cells in $25 \mathrm{~mL}$ of $1 \times$ PBS and transfer the thick cell suspension to a $50 \mathrm{~mL}$ falcon tube using a $10 \mathrm{~mL}$ pipet.

14. Centrifuge the cells at $7068 \times \mathrm{g}$ at $4{ }^{\circ} \mathrm{C}$ for $25 \mathrm{~min}$ and discard the $1 \times$ PBS supernatant.

15. II PAUSE STEP: Store the pelleted cells at $-80^{\circ} \mathrm{C}$ until the next day or when ready for cell lysis.

\subsection{Aß(M1-42) Peptide Purification Using Reverse-Phase HPLC. Time for Completion: 05:40 h}

3.3.1. Cell Lysis and Resuspension. Time for Completion: 02:24 h

Note: Cell lysis steps involving sonication and centrifugation is performed at $4{ }^{\circ} \mathrm{C}$ to prevent denaturation of the protein. It is critical for the $\mathrm{pH}$ of the buffers to be set at 8.0 to improve solubility of the peptide and prevent its aggregation. The peptide is thus maintained in alkaline conditions since it is known to aggregate at lower $\mathrm{pH}$ of 5.5. with lower solubility [15].

1. To lyse the cells (Figure 1, Part 4), resuspend the cell pellet in $25 \mathrm{~mL}$ Buffer A. Cut the tip off a $1 \mathrm{~mL}$ pipette tip to efficiently dissociate the thick pellet in the buffer.

2. Disrupt the cell pellet mechanically by mixing the cells with Buffer A. Place the tube in an ice bucket containing ice and water and introduce the sonicator probe into the cell mixture. Note: Ensure that the cell mixture remains cold throughout the sonication.

3. Sonicate the cells at $30 \mathrm{~s}$ pulse with an amplitude of $60 \%$ for $2 \mathrm{~min}$ until the lysate appears homogenous. Note: Four $30 \mathrm{~s}$ on/off cycles for a total of $4 \mathrm{~min}$.

1 CRITICAL STEP: To increase the lysis efficiency, sonicate the cell pellet in the original $50 \mathrm{~mL}$ frozen falcon tube since transferring the cell mixture to containers with a large surface area reduces the lysis efficiency.

4. Centrifuge the sonicated mixture at $7068 \times \mathrm{g}$ for $25 \mathrm{~min}$ at $4{ }^{\circ} \mathrm{C}$ and discard the supernatant. Note: The sonicated mixture was centrifuged at $7068 \times \mathrm{g}$ based on the maximum speed allowed on our centrifuge and swinging bucket rotor (see Section 2.2 Equipment). This speed was sufficient to collect the pellet from the cell lysis at the bottom of the tube. The sonicated mixture may also be centrifuged at higher speeds of up to $38,000 \times \mathrm{g}$ if using the JA-18 rotor to collect the pellet [14].

5. Repeat the sonication and centrifugation steps (steps 1 to 4 ) three more times.

6. Resuspend the pellet in $20 \mathrm{~mL}$ of freshly prepared Buffer B and sonicate as above until the solution appears clear.

1 CRITICAL STEP: Purification should be performed immediately after the peptide is dissolved in $8 \mathrm{M}$ urea solution (Buffer B). Extended exposure of the peptide to urea is known to cause carbamylation of lysine residues. 
4 CRITICAL STEP: Due to the inconsistencies of mechanical lysis using the sonicator, the solution may appear to be cloudy. Note: Prepare fresh Buffer B every time. The $\mathrm{pH}$ of the buffers is critical for the complete dissolution of the peptide fraction.

7. Centrifuge the solution at $7068 \times \mathrm{g}$ for $25 \mathrm{~min}$ at $4{ }^{\circ} \mathrm{C}$ to remove any foam that may have appeared during the sonication step and to pellet unwanted insoluble cell debris, if any. Finally, filter the supernatant through a $0.22 \mu \mathrm{m}$ non-sterile hydrophilic PVDF syringe filter using a $30 \mathrm{~mL}$ syringe to obtain a clear solution.

8. OPTIONAL STEP: Prior to purification, MALDI-TOF MS may be performed on the urea-solubilized recombinant peptide to confirm the presence of $A \beta(M 1-42)$ in the solution (data not shown). Since the solution contains additional salts, the solution must be passed through a C18 Zip Tip resin to remove the salts in order to obtain a clear spectrum.

\subsubsection{Peptide Purification Using Reverse-Phase HPLC. Time for Completion: 03:16 h}

Equipment set-up for peptide purification: Heat a water bath containing reverse osmosis water using a commercially-available sous vide between 60 to $80^{\circ} \mathrm{C}$ (Figure 3A). Completely submerge both the guard and the primary columns in the water bath (Figure 3B). It is recommended to set up the water bath with the submerged columns at least 4 hours prior to purification to allow the water bath to reach 60 to $80^{\circ} \mathrm{C}$ and the temperature of the columns to equilibrate. Note: As it is common for many silica-based C18 columns to degrade at higher temperatures, different columns have different recommended heating limits. Refer to your column manual or manufacturing guide to identify the column's recommended heating limit. Heating of the guard and primary columns is necessary to prevent the recombinant peptide from sticking to the column and to improve yield of the peptide.
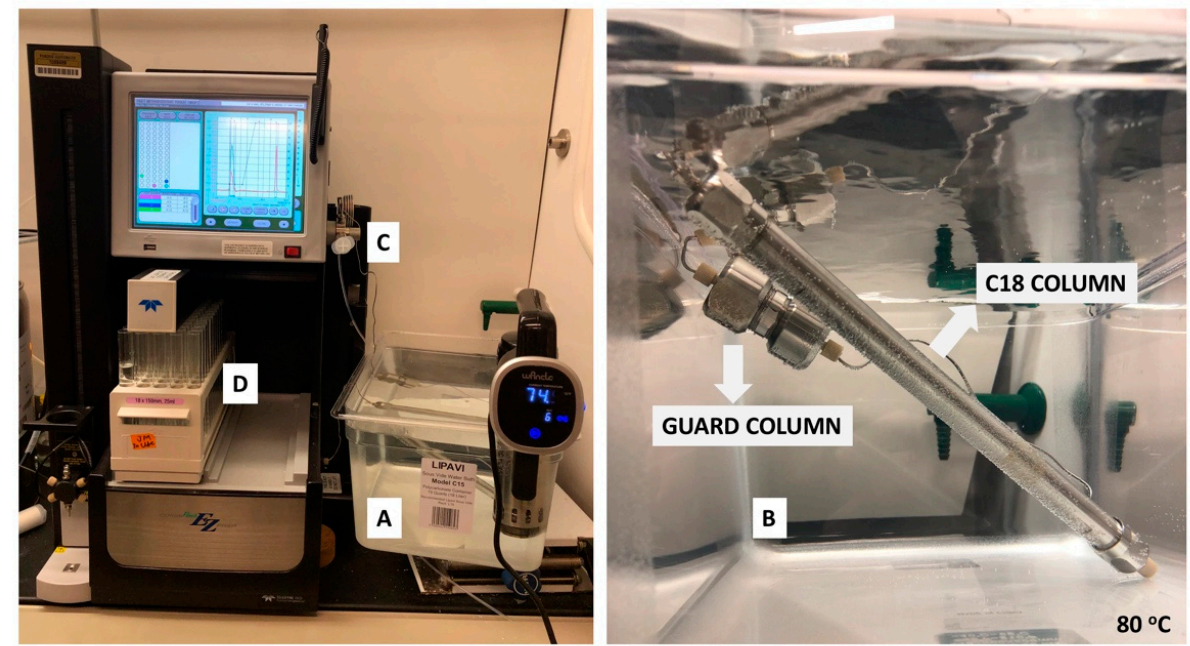

Figure 3. High-performance liquid chromatography (HPLC) set-up. A. The water bath containing filtered reverse osmosis water is heated to around $80^{\circ} \mathrm{C}$. B. Both columns are completely submerged in the water bath. One end of the guard column attached to the injection valve with metal tubing and the other end of the guard column attached to the inlet of the primary C18 $100 \AA 5 \mu \mathrm{m} 10 \mathrm{~mm} \times$ $250 \mathrm{~mm}$ preparative column. The primary column is fed into the Combiflash. C. $5 \mathrm{~mL}$ injection loop. D. Collection of $A \beta(M 1-42)$ fractions eluted at $26 \mathrm{~min}$.

Place the solvent lines from the CombiFlash HPLC instrument into the Solvent A and Solvent B bottles. Next, prime the system with Solvent B followed by Solvent A to clear the solvent lines of any previous residual solvents. Then clean the column by injecting $4 \mathrm{~mL}$ of Buffer B into the $5 \mathrm{~mL}$ injection loop (Figure 3C) and run the solvent gradient for the cleaning protocol provided in Table 1.

1. Place a rack of clean and dry $18 \times 150 \mathrm{~mm}$ glass test tubes (Figure 3D) in the instrument.

2. Run the solvent gradient as per the cleaning protocol in Table 1 at a flow rate of $5 \mathrm{~mL} / \mathrm{min}$. 
3. Equilibrate the column with the starting solvent system in Table 2 at a flow rate of $5 \mathrm{~mL} / \mathrm{min}$. And inject $4 \mathrm{~mL}$ of the filtered solution obtained from Section 3.2.1 step 8 into the HPLC injection loop for separation (Figure 3C).

4. Run the solvent gradient described in Table 2 and collect peaks detected at $214 \mathrm{~nm}$. Note: A $\beta$ (M1-42) typically elutes at 26 min.

5. Upon completion of the purification protocol, clean the column with the solvent gradient described in Table 1.

6. Repeat the cleaning and purification steps three more times or until all the solution is used.

7. Combine the collected $A \beta(M 1-42)$ fractions eluted at 26 min (Figure 4).

8. Evaporate off the acetonitrile under reduced pressure at $65^{\circ} \mathrm{C}$ using a rotary evaporator until a cloudy aqueous solution remains.

9. Freeze the solution at $-80^{\circ} \mathrm{C}$ and then submerge in liquid nitrogen for $5 \mathrm{~min}$.

10. Perform overnight lyophilization at $-90^{\circ} \mathrm{C}$ at 0.003 mbar pressure to obtain the white $\mathrm{A} \beta(\mathrm{M} 1-42)$ powder (Figure 4).

11. (I) PAUSE STEP Store the lyophilized peptide at $-80^{\circ} \mathrm{C}$ until further characterization.

Table 2. Solvent gradient for peptide purification.

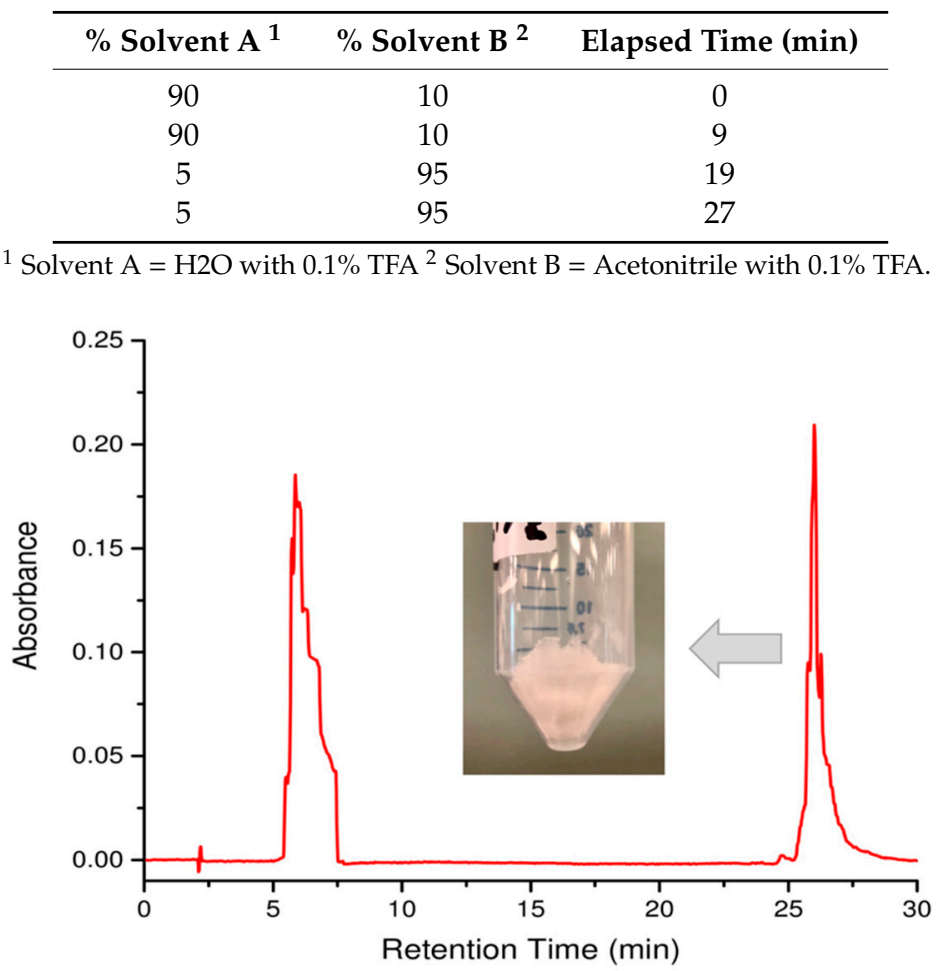

Figure 4. HPLC Chromatogram of urea-solubilized recombinant protein during purification. The A $\beta(\mathrm{M} 1-42)$ peak elutes at $26 \mathrm{~min}$ at $95 \%$ acetonitrile with $0.1 \%$ TFA, $5 \% \mathrm{H}_{2} \mathrm{O}$ with $0.1 \%$ TFA. The urea salt from solution B elutes as a cluster of peaks between 5-7 min in 10\% acetonitrile with $0.1 \%$ TFA, $90 \% \mathrm{H}_{2} \mathrm{O}$ with $0.1 \%$ TFA. The absorbance was taken at $214 \mathrm{~nm}$. Inserted image of the white powder is the lyophilized peptide corresponding to the $\mathrm{A} \beta(\mathrm{M} 1-42)$ fractions collected at $26 \mathrm{~min}$.

\subsection{Characterization of $A \beta(M 1-42)$}

3.4.1. Characterization of A $\beta(\mathrm{M} 1-42)$ Using MALDI-TOF MS and High-Resolution LC-MS. Time for Completion: 00:45 h

1. Dissolve a small quantity of $\mathrm{A} \beta(\mathrm{M} 1-42)$ in water and dilute in water until the sample is approximately $100 \mu \mathrm{g} / \mathrm{mL}$. 
2. Thoroughly mix $1 \mu \mathrm{L}$ of the $\mathrm{A} \beta(\mathrm{M} 1-42)$ solution (analyte) with $1 \mu \mathrm{L}$ of $\alpha$-cyano-4-hydroxycinnamic acid (CHCA) matrix solution ( $10 \mathrm{mg} / \mathrm{mL}$ CHCA in $0.1 \%$ TFA).

3. Spot the analyte/matrix mixture on a MALDI target plate and allow to dry.

4. Obtain the MALDI-TOF mass spectra on a Voyager-DE PRO from 1000-22000 Da in the positive ion mode with an accelerating voltage of 25,000 V (Figure 5).

5. Further dilute the analyte solution prepared for the MALDI-TOF MS and inject into the Agilent 6550 iFunnel Q-TOF LC-MS in positive mode and fragment using electrospray ionization (ESI) with a fragmentor voltage of $175 \mathrm{~V}$ (Figure 6).
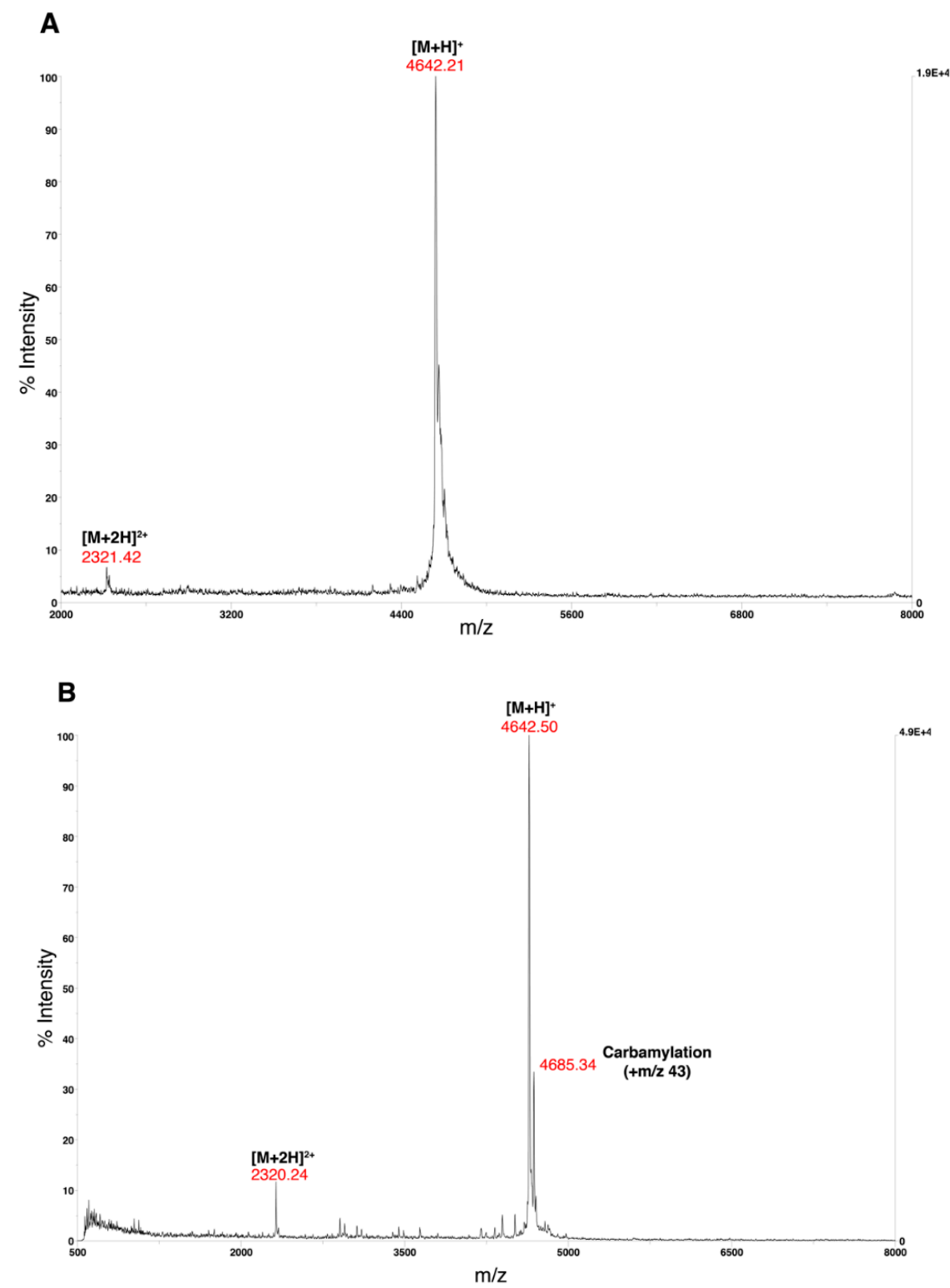

Figure 5. MALDI-TOF mass spectra of $A \beta(M 1-42)$. A. The MALDI-TOF mass spectra of lyophilized $\mathrm{A} \beta(\mathrm{M} 1-42)$ in the range of $\mathrm{m} / \mathrm{z} 2000$ to 8000 . The $\mathrm{A} \beta(\mathrm{M} 1-42)$ corresponds to the $\mathrm{m} / \mathrm{z} 4642.21$ peak. B. MALDI-TOF mass spectra of lyophilized carbamylated A $\beta(M 1-42)$ in the range of $\mathrm{m} / \mathrm{z} 500$ to 8000. Carbamylation peak (m/z 4685.34) appears m/z 43 higher than the $\mathrm{A} \beta(\mathrm{M} 1-42)$ at $\mathrm{m} / \mathrm{z} 4642.50$ due to the extended exposure of the peptide to urea. A Voyager De-Pro MALDI-TOF mass spectrometer in positive linear mode was used with CHCA solution as the matrix for each spectrum. 


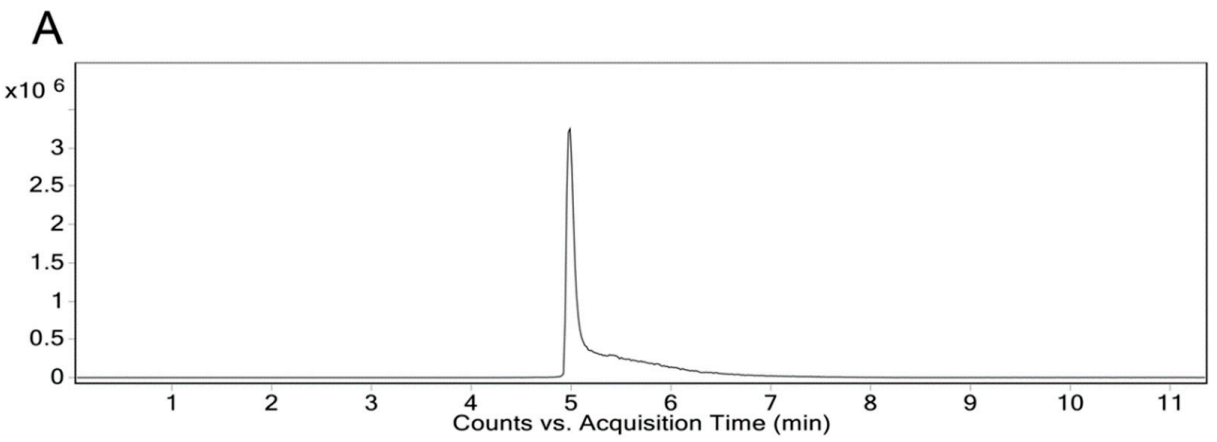

B

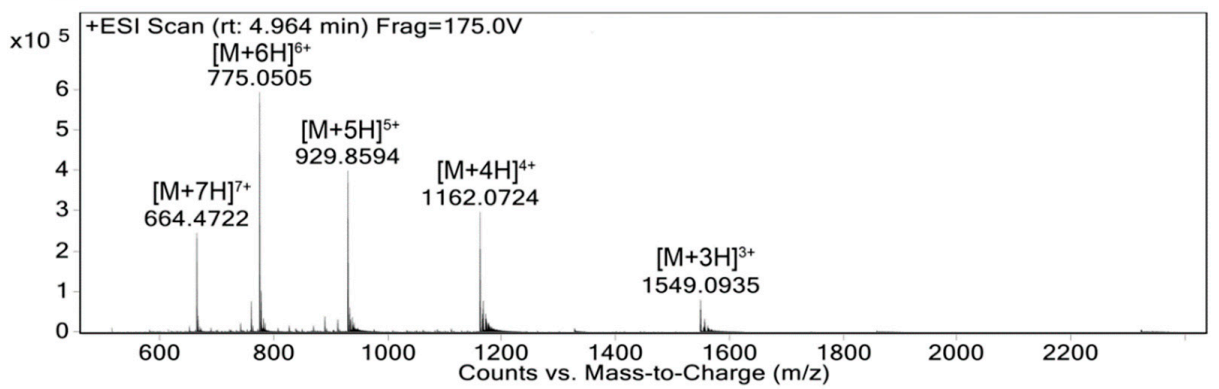

C

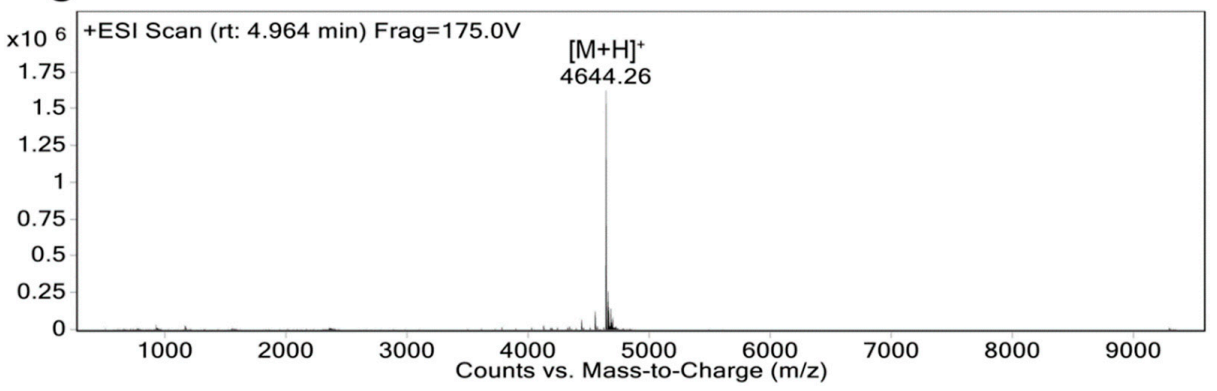

Figure 6. High-resolution Liquid Chromatography-Mass Spectrum (LC-MS) of A $\beta(M 1-42)$. The high-resolution mass spectrum was obtained using an Agilent 6550 iFunnel Q-TOF LC-MS in positive ion mode using electrospray ionization (ESI) with a fragmentor voltage of $175 \mathrm{~V}$. A. The chromatogram from the LC-MS showed a significant peak between 5-7 min while using $0.1 \%$ formic acid and methanol as the solvent system. B. Mass spectrum at time point 4.964 min resulting in the corresponding peaks: $[\mathrm{M}+3 \mathrm{H}]^{3+}\left(\mathrm{m} / \mathrm{z}\right.$ 1549.0935), $[\mathrm{M}+4 \mathrm{H}]^{4+}\left(\mathrm{m} / \mathrm{z}\right.$ 1162.0724), $[\mathrm{M}+5 \mathrm{H}]^{5+}(\mathrm{m} / \mathrm{z}$ 929.8594), $[\mathrm{M}+6 \mathrm{H}]^{6+}(\mathrm{m} / \mathrm{z} 775.0505)$, and $[\mathrm{M}+7 \mathrm{H}]^{7+}(\mathrm{m} / \mathrm{z}$ 664.4722). C. The deconvolution of the mass spectrum in

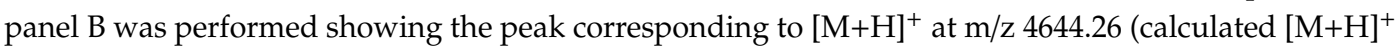
of $\mathrm{m} / \mathrm{z}$ was done using the PEPTIDEMASS program).

3.4.2. Western Blot Characterization of the Purified A $\beta($ M1-42) Peptide. Time for Completion: Two Days

1. To perform western blotting, the lyophilized peptide from HPLC was dissolved in 1,1,1,3,3,3-hexafluoro-2-propanol (HFIP) to prepare monomers of $\mathrm{A} \beta(\mathrm{M} 1-42)$ as per the previously established protocols [16,17].

2. When the peptide is dried overnight in the chemical hood, dissolve $1 \mathrm{mg}$ of the peptide in $221 \mu \mathrm{L}$ DMSO to obtain a final concentration of $1.0 \mathrm{mM}$.

3. Load the peptide on $12 \%$ Sodium Dodecyl Sulfate Polyacrylamide Gel Electrophoresis (SDS-PAGE) at different concentrations $(10,20$, and $40 \mu \mathrm{g}$ per $40 \mu \mathrm{L}$ total well volume) and run the gel at $115 \mathrm{~V}$ for $1 \mathrm{~h}$ and $20 \mathrm{~min}$ or until the loading buffer line reaches the bottom of the gel.

4. Transfer the gel to a nitrocellulose membrane at $10 \mathrm{~V}$ for $35 \mathrm{~min}$. 
5. After transfer, boil the membrane in PBS for $5 \mathrm{~min}$, then incubate on a rocker with blocking buffer (5\% milk in Tris-buffered saline, $0.1 \%$ Tween 20 (TBST)) for $1 \mathrm{~h}$.

6. After blocking, incubate the membrane in the blocking buffer containing the $6 \mathrm{E} 10$ monoclonal antibody (with target specificity to the human $\mathrm{A} \beta$ peptide) overnight on a rocker at $4{ }^{\circ} \mathrm{C}$.

7. The next morning, wash the membrane 3 times for 10 min each with TBST and incubate with the secondary antibody (HRP-conjugated goat anti-mouse antibody) on the rocker for $1 \mathrm{~h}$.

8. Washed again three times for 10 min each with TBST and develop in the dark room using chemiluminescence reagents as per the manufacturer's protocol.

9. Run the synthetic $A \beta(1-42)$ in the same gel with the same protocol for comparison (Figure 7).

A. Recombinant human Abeta (M1-42)

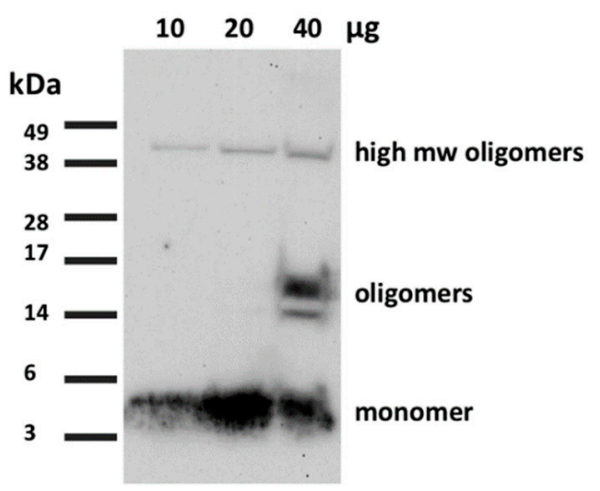

B. Synthetic human Abeta (1-42)

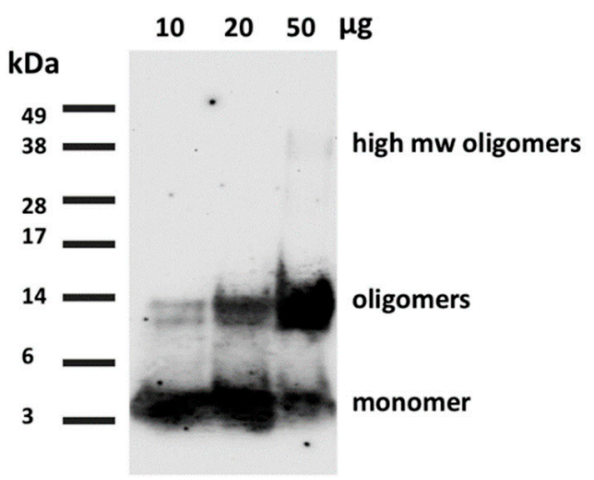

Figure 7. Western blot characterization of the recombinant human $\mathrm{A} \beta(\mathrm{M} 1-42)$ peptide. A. 10, 20, and $40 \mu \mathrm{g}$ of the recombinant $\mathrm{A} \beta(\mathrm{M} 1-42)$ peptide was run on an SDS-PAGE gel and bands visualized using the $6 \mathrm{E} 10$ antibody with Western Blot. Lower concentrations of 10 and $20 \mu \mathrm{g}$ show monomeric bands at $4 \mathrm{kDa}$ while the $40 \mu \mathrm{g}$ lane shows oligomeric bands at $14-17 \mathrm{kDa}$ along with the monomeric band. All 3 concentrations show a slight amount of high molecular weight bands at 38-49 kDa suggesting a few aggregated forms of the peptide in the mixture. B. Synthetic human A $\beta 1-42$ for reference shows similar monomeric bands at 10,20, and $50 \mu \mathrm{g}$ concentrations. More oligomers are present in the synthetic peptide.

3.4.3. Characterization of A $\beta(\mathrm{M} 1-42)$ Oligomers by Atomic Force Microscopy. Time for Completion: Two days

Preparing A $\beta$ (M1-42) monomers: The synthetic $A \beta(1-42)$ and the lyophilized $A \beta(M 1-42)$ powder are used to prepare $1 \mathrm{mM}$ solution with $215 \mu \mathrm{L}$ of 1,1,1,3,3,3-Hexafluoro-2-propanol (HFIP). Handle the HFIP carefully using a $1 \mathrm{~mL}$ glass Hamilton syringe with a Teflon plunger and a sharp needle. Start by incubating the clear $A \beta(M 1-42)$ and synthetic $A \beta(1-42)$ solution at room temperature for $30 \mathrm{~min}$. Next, transfer $100 \mu \mathrm{L}$ aliquots $(\sim 0.45 \mathrm{mg})$ to microcentrifuge tubes and leave the tubes open in the fume hood overnight for the HFIP to evaporate. The next morning, dry the sample under high vacuum for $1 \mathrm{~h}$ without heating to remove any remaining traces of HFIP and moisture. This results in thin clear films of monomeric peptides at the bottom of the tubes which are stored at $-80^{\circ} \mathrm{C}$ until further use.

1. To evaluate the aggregation property of the recombinant $A \beta(M 1-42)$ with respect to the synthetic $\mathrm{A} \beta(1-42)$, the protocol established by Stine et al. is used to prepare $\mathrm{A} \beta$ oligomers and fibrils $[16,17]$.

2. In brief, allow the tubes containing monomeric peptide films to equilibrate at room temperature for a few minutes and prepare $5 \mathrm{mM}$ of synthetic $\mathrm{A} \beta(1-42)$ and recombinant $\mathrm{A} \beta(\mathrm{M} 1-42) \mathrm{DMSO}$ stocks by adding $20 \mu \mathrm{L}$ of cell-grade DMSO to each tube containing $\sim 0.45 \mathrm{mg}$ of the peptide.

3. Pipet the solution thoroughly by scraping down the sides of the tube and vortexed for $\sim 30 \mathrm{~s}$ followed by bath sonication for $10 \mathrm{~min}$ to ensure complete resuspension of the peptide film. 
4 CRITICAL STEP: This stock solution is used immediately as the starting material for oligomeric A $\beta$ preparation.

4. To prepare $A \beta$ oligomers, mix $2 \mu \mathrm{L}$ of the freshly resuspended $5 \mathrm{mM}$ of synthetic $A \beta(1-42)$ and recombinant $\mathrm{A} \beta(\mathrm{M} 1-42)$ in DMSO with $98 \mu \mathrm{L}$ of $1 \times$ PBS (filtered) to make $100 \mu \mathrm{M}$ solution. To prepare $\mathrm{A} \beta$ fibrils, mix $98 \mu \mathrm{L}$ of $10 \mathrm{mM} \mathrm{HCl}$ (filtered) to $2 \mu \mathrm{L}$ of freshly resuspended $5 \mathrm{mM}$ of recombinant $\mathrm{A} \beta(\mathrm{M} 1-42)$ in DMSO.

5. Vortex the solution thoroughly for $15 \mathrm{~s}$ and incubate at $4{ }^{\circ} \mathrm{C}$ (for oligomers) and at $37^{\circ} \mathrm{C}$ (for fibrils) for $24 \mathrm{~h}$.

6. After $24 \mathrm{~h}$, prepare the samples for AFM with proper sterile technique in the hood as follows: Dilute the $100 \mu \mathrm{M}$ samples to a concentration of $30 \mu \mathrm{M}$ in filtered water.

7. Mount the mica sheet on $15 \mathrm{~mm}$ stainless steel pucks.

8. Immediately before sample plating, remove a few layers of the mica sheet using adhesive tape to reveal a featureless surface for the absorption of the peptide.

9. Next, pretreat the mica surface with $\sim 5-8 \mu \mathrm{L}$ of filtered $1 \mathrm{M} \mathrm{HCl}$ for $30 \mathrm{~s}$ and rinse with $2-3$ drops of ultrapure water (filtered) using the $1 \mathrm{~mL}$ syringe.

10. 4 CRITICAL STEP: Hold the mica plate at a $45^{\circ}$ angle to wash with drops of water. Immediately after cleaning, spot the peptide sample onto mica and incubate for $3 \mathrm{~min}$.

11. Gently rinse the mica with 2-3 drops of water using the $1 \mathrm{~mL}$ syringe and dry with several gentle pulses of clean compressed air or nitrogen gas.

12. Incubate the samples at room temperature for a few hours until imaging.

13. Perform the AFM imaging using a multimode AFM equipped with aluminum-coated silicon probes with $\sim 300 \mathrm{kHz}$ resonant frequency and $40 \mathrm{~N} / \mathrm{m}$ force constant under the tapping mode.

14. Finally, perform image analysis using the NanoScope Analysis software.

\section{Expected Results and Discussion}

A handful of methodologies have been published in recent years that show expression of $A \beta 42$ in E. coli using standard molecular biology techniques, such as transformation and bacterial cell culture. The major differences among these methodologies have been the isolation and purification methods used to obtain purified peptide samples. The purification of the peptides expressed from cells is challenging due to the many different techniques proposed combined with limited resources available in a traditional biochemistry or chemical biology laboratory. For example, previously, nickel affinity chromatography was used to purify A $\beta 42$ fusion proteins with N-terminal His-affinity tag [18] or as an extended polypeptide of His-tagged ubiquitin [19]. Both these methods require additional steps from which $A \beta 42$ has to be eventually cleaved requiring extra time, reagents, as well as comprising on the final peptide yield. Another method used $\mathrm{NaOH}$ treatment followed by ultracentrifugation to isolate and purify the insoluble inclusion bodies expressed in the E. coli [20]. This purification method reduces the peptide purity and yield ( $4 \mathrm{mg}$ of peptide obtained). Walsh et al. [12] used ion exchange chromatography and Yoo et al. [14] used preparative HPLC equipped with a C8 column for $\mathrm{A} \beta(\mathrm{M} 1-42)$ purification.

In this paper, we present a highly detailed alternate and refined approach for the rapid, easy, and low-cost production and purification of recombinant human A $\beta 42$. By using alternate tools for peptide purification, we provide additional versatility to the protocol. Expected results and some critical points of consideration during the protocol are as follows. During the cell lysis and resuspension step, it is important to avoid leaving the peptide in $8 \mathrm{M}$ urea after cell lysis for a long period of time. Exposing the lysate to a high concentration of urea solution is known to cause carbamylation of the lysine residues [21]. Carbamylation can be seen in the MALDI-TOF MS by the presence of a secondary peak $\mathrm{m} / \mathrm{z} 43$ higher than the peak $\mathrm{m} / \mathrm{z} 4642.50$ corresponding to $[\mathrm{M}+\mathrm{H}]^{+}$(Figure 5B). Our HPLC system has a $5 \mathrm{~mL}$ injection loop, which limits the amount of sample that can be loaded onto the column. In Yoo et al. method, the cell lysate in $8 \mathrm{M}$ urea was further diluted before injecting in the column [14]. 
We decided not to dilute the urea-solubilized fraction of the cell lysate in our protocol due to the smaller volume of the injection loop allowing for fewer batch runs thereby reducing the time taken for purification without reducing the purity of the peptide. The mass characterization of the final peptide shows that the final peptide obtained with very few impurities (Figure 6).

Using western blotting of recombinant $A \beta(M 1-42)$ and synthetic $A \beta 42$, we demonstrated that the purified peptide mixture contains large quantities of monomers as seen in the $4 \mathrm{kDa}$ region (Figure 7). A higher concentration of the peptide shows oligomeric forms of the peptide that appear between 14-17 kDa (trimers and tetramers). Overall, we show that the recombinant A $\beta(\mathrm{M} 1-42)$ peptide epitope can be recognized by the monoclonal $6 \mathrm{E} 10$ antibody that is specific for human $\mathrm{A} \beta 42$, suggesting future biological use of our recombinant $A \beta(M 1-42)$. Interestingly, the recombinant $A \beta(M 1-42)$ peptide showed higher molecular weight (HMW) oligomeric bands in the 38-49 kDa region that were not visible with synthetic $A \beta 42$. Increased levels of such HMW oligomers are seen in the cerebrospinal fluid samples from Alzheimer's patients [22]. Thus, HMW oligomers are of huge importance for understanding the etiology of Alzheimer's disease [23]. We further characterized the aggregation property of recombinant $\mathrm{A} \beta(\mathrm{M} 1-42)$ using atomic force microscopy (AFM). The recombinant peptide formed large oligomers of different sizes (some greater than $20 \mathrm{~nm}$, not shown) compared to the synthetic peptide that formed mostly uniform oligomers during the same time (Figure 8). The recombinant $\mathrm{A} \beta(\mathrm{M} 1-42)$ also formed characteristic fibrils similar to those formed by synthetic A $\beta 42$ [17]. It has been previously shown that the recombinant $A \beta 42$ aggregates faster and is more neurotoxic than synthetic $A \beta 42$ [11]. Overall, the recombinant $A \beta(M 1-42)$ formed characteristic oligomers under similar aggregation conditions as the synthetic $A \beta 42$. Further characterization may be necessary to evaluate the concentration-dependent aggregation kinetics of the recombinant A $\beta(\mathrm{M} 1-42)$ [13].

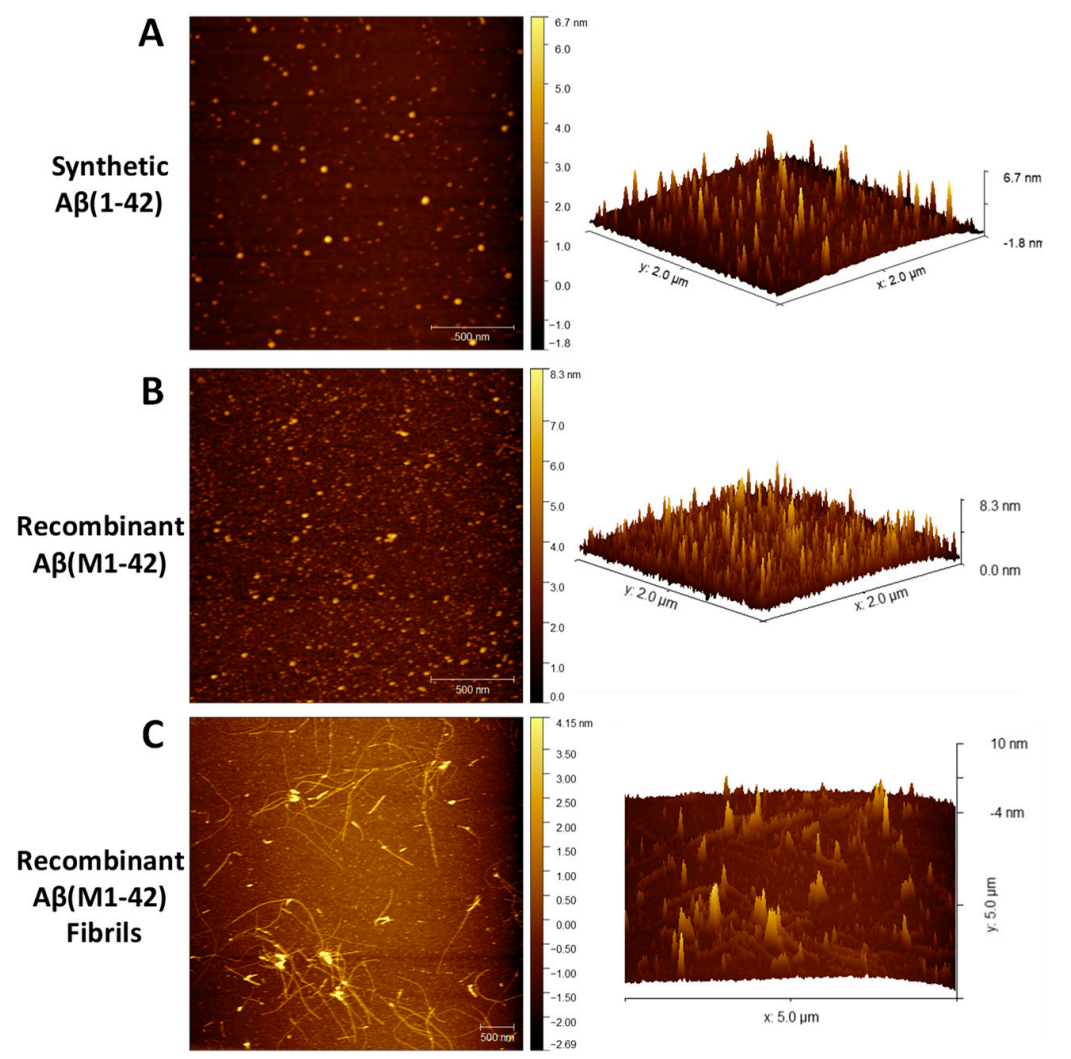

Figure 8. AFM characterization of the recombinant human $A \beta(M 1-42)$ peptide. The (A) synthetic $A \beta(1-42)$ oligomers and (B) recombinant $A \beta(M 1-42)$ oligomers and/or (C) fibrils were prepared from HFIP- treated peptide films in $1 \times$ PBS buffer ( $\mathrm{pH} 7.4$ ) and analyzed by atomic force microscopy (AFM). Images (A) and (B) are $2 \times 2 \mu \mathrm{m} x-y$ scale and image (C) is $5 \times 5 \mu \mathrm{m} x-y$ scale. Left. 2-D image. Right. 3-D image. 
Thus, the $A \beta(M 1-42)$ peptide could be used for several downstream in vitro and in vivo applications such as cell-based drug screening, neuroinflammation cell culture, animal models, etc., and for the synthesis and development of novel $A \beta$-related biorthogonal chemical and fluorescent probes to facilitate the advancement of neurological disease research.

Author Contributions: Conceptualization, P.P., T.C.L., and G.C.; methodology, P.P., T.C.L., and K.P.J.; validation, P.P., T.C.L., and K.P.J.; investigation, P.P., T.C.L., and K.P.J.; resources, G.C.; writing-original draft preparation, P.P.; writing-review and editing, T.C.L., K.P.J., and G.C.; supervision, G.C.; project administration, G.C.; funding acquisition, G.C.

Funding: This research was supported by Startup Funds to G.C. from Department of Chemistry, Purdue University and Purdue Research Foundation (PRF) Research Grant award to G.C. The authors acknowledge the support from the Purdue University Center for Cancer Research, NIH grant P30 CA023168.

Acknowledgments: We thank the following individuals at Purdue University: Herman Sintim at Department of Chemistry for providing the Rosetta(DE3)pLysS cells and the resources for bacterial work including the laminar flow cabinet, sonicator, $37^{\circ} \mathrm{C}$ incubator, and shaker; Gregory H. Hockerman at Department of Medicinal Chemistry and Molecular Pharmacology for providing the BL21(DE3)pLysS cells; Connie Bonham at Analytical Mass Spectrometry Facility for assistance with MALDI-TOF/MS.

Conflicts of Interest: The authors declare no conflict of interest.

\section{References}

1. Hamley, I.W. The Amyloid Beta Peptide: A Chemist's Perspective. Role in Alzheimer's and Fibrillization. Chem. Rev. 2012, 112, 5147-5192. [CrossRef] [PubMed]

2. Jarrett, J.T.; Berger, E.P.; Lansbury, P.T. The carboxy terminus of the beta. amyloid protein is critical for the seeding of amyloid formation: Implications for the pathogenesis of Alzheimer's disease. Biochem. 1993, 32, 4693-4697. [CrossRef] [PubMed]

3. Murphy, M.P.; Levine, H. Alzheimer's Disease and the $\beta$-Amyloid Peptide. J. Alzheimer's Dis. 2010, 19, 311-323. [CrossRef] [PubMed]

4. Ballard, C.; Gauthier, S.; Corbett, A.; Brayne, C.; Aarsland, D.; Jones, E. Alzheimer's Disease. Lancet 2011, 377, 1019-1031. [CrossRef]

5. Doig, A.J.; Del Castillo-Frias, M.P.; Berthoumieu, O.; Tarus, B.; Nasica-Labouze, J.; Sterpone, F.; Nguyen, P.H.; Hooper, N.M.; Faller, P.; Derreumaux, P. Why Is Research on Amyloid- $\beta$ Failing to Give New Drugs for Alzheimer's Disease? ACS Chem. Neurosci. 2017, 8, 1435-1437. [CrossRef] [PubMed]

6. Cummings, J.; Lee, G.; Ritter, A.; Zhong, K. Alzheimer's Disease Drug Development Pipeline: 2018. Alzheimer's Dement. Transl. Res. Clin. Interv. 2018. [CrossRef]

7. Zuroff, L.; Daley, D.; Black, K.L.; Koronyo-Hamaoui, M. Clearance of cerebral A $\beta$ in Alzheimer's disease: Reassessing the role of microglia and monocytes. Cell. Mol. Life Sci. 2017, 74, 2167-2201. [CrossRef] [PubMed]

8. Frost, G.R.; Li, Y.-M. The role of astrocytes in amyloid production and Alzheimer's disease. Open Boil. 2017, 7, 170228. [CrossRef] [PubMed]

9. Gomez-Arboledas, A.; Davila, J.C.; Sanchez-Mejias, E.; Navarro, V.; Nuñez-Diaz, C.; Sanchez-Varo, R.; Sanchez-Mico, M.V.; Trujillo-Estrada, L.; Fernandez-Valenzuela, J.J.; Vizuete, M.; et al. Phagocytic Clearance of Presynaptic Dystrophies by Reactive Astrocytes in Alzheimer's Disease. Glia 2018. [CrossRef] [PubMed]

10. Tickler, A.K.; Clippingdale, A.B.; Wade, J.D. Amyloid- $\beta$ as a "Difficult Sequence" in Solid Phase Peptide Synthesis. Protein Pept. Lett. 2004. [CrossRef]

11. Finder, V.H.; Vodopivec, I.; Nitsch, R.M.; Glockshuber, R. The Recombinant Amyloid- $\beta$ Peptide A $\beta 1-42$ Aggregates Faster and Is More Neurotoxic than Synthetic A $\beta 1-42$. J. Mol. Boil. 2010, 396, 9-18. [CrossRef] [PubMed]

12. Walsh, D.M.; Thulin, E.; Minogue, A.M.; Gustavsson, N.; Pang, E.; Teplow, D.B.; Linse, S. A facile method for expression and purification of the Alzheimer's disease-associated amyloid $\beta$-peptide. FEBS J. 2009, 276, 1266-1281. [CrossRef] [PubMed]

13. Szczepankiewicz, O.; Linse, B.; Meisl, G.; Thulin, E.; Frohm, B.; Frigerio, C.S.; Colvin, M.T.; Jacavone, A.C.; Griffin, R.G.; Knowles, T.; et al. N-Terminal Extensions Retard A $\beta 42$ Fibril Formation but Allow Cross-Seeding and Coaggregation with A $\beta 42$. J. Am. Chem. Soc. 2015, 137, 14673-14685. [CrossRef] [PubMed] 
14. Yoo, S.; Zhang, S.; Kreutzer, A.G.; Nowick, J.S. An Efficient Method for the Expression and Purification of A $\beta$ (M1-42). Biochemistry 2018. [CrossRef] [PubMed]

15. Teplow, D.B. Preparation of Amyloid $\beta$-Protein for Structural and Functional Studies. Methods in Enzymology 2006, 413, 20-33.

16. Stine, W.B.; Dahlgren, K.N.; Krafft, G.A.; LaDu, M.J. In Vitro Characterization of Conditions for Amyloid- $\beta$ Peptide Oligomerization and Fibrillogenesis. J. Biol. Chem. 2003. [CrossRef] [PubMed]

17. Stine, W.B.; Jungbauer, L.; Yu, C.; Ladu, M.J. Preparing Synthetic A $\beta$ in Different Aggregation States. Methods Mol. Biol. 2011. [CrossRef]

18. Chhetri, G.; Pandey, T.; Chinta, R.; Kumar, A.; Tripathi, T. An improved method for high-level soluble expression and purification of recombinant amyloid-beta peptide for in vitro studies. Protein Expr. Purif. 2015, 114, 71-76. [CrossRef]

19. Lee, E.K.; Hwang, J.H.; Shin, D.Y.; Kim, D.I.; Yoo, Y.J. Production of recombinant amyloid- $\beta$ peptide 42 as an ubiquitin extension. Protein Expr. Purif. 2005, 40, 183-189. [CrossRef]

20. Hoarau, M.; Malbert, Y.; Irague, R.; Hureau, C.; Faller, P.; Gras, E.; André, I.; Remaud-Siméon, M. A Robust and Efficient Production and Purification Procedure of Recombinant Alzheimers Disease Methionine-Modified Amyloid- $\beta$ Peptides. PLOS ONE 2016. [CrossRef]

21. Sun, S.; Zhou, J.Y.; Yang, W.; Zhang, H. Inhibition of Protein Carbamylation in Urea Solution Using Ammonium-Containing Buffers. Anal. Biochem. 2014. [CrossRef] [PubMed]

22. Fukumoto, H.; Tokuda, T.; Kasai, T.; Ishigami, N.; Hidaka, H.; Kondo, M.; Allsop, D.; Nakagawa, M. High-molecular-weight $\beta$-amyloid oligomers are elevated in cerebrospinal fluid of Alzheimer patients. FASEB J. 2010, 24, 2716-2726. [CrossRef] [PubMed]

23. Bernstein, S.L.; Dupuis, N.F.; Lazo, N.D.; Wyttenbach, T.; Condron, M.M.; Bitan, G.; Teplow, D.B.; Shea, J.-E.; Ruotolo, B.T.; Robinson, C.V.; et al. Amyloid- $\beta$ protein oligomerization and the importance of tetramers and dodecamers in the aetiology of Alzheimer's disease. Nat. Chem. 2009, 1, 326-331. [CrossRef] [PubMed]

(C) 2019 by the authors. Licensee MDPI, Basel, Switzerland. This article is an open access article distributed under the terms and conditions of the Creative Commons Attribution (CC BY) license (http://creativecommons.org/licenses/by/4.0/). 